\title{
Domestic Violence: Prevalence And Its Psycho-Social Impacts On Women In Pukhtoon Society
}

\author{
Mamoon Khan Khattak \\ Department of Social Work \\ Kohat University of Science \& Technology (KUST), Kohat \\ Aamir Khan Bangash \\ Department of Sociology \\ Kohat University of Science \& Technology (KUST), Kohat \\ Sabir Michael \\ Department of Social Work \\ University of Karachi \\ Zubaida Khatoon Khattak \\ Department of Economics \\ University of Peshawar
}

\begin{abstract}
The women are affected by many forms of violence; most often inside the most secure environments i.e. of their own homes. Women are suffering in our societies due to socio-cultural values, misinterpretation of religious teachings, their subordinate status and lack of legal protection. The impacts of domestic violence go beyond the family and affect not only the victims but society as a whole. The basic purpose of this research was to know the views and experience of married women about psycho social impacts and forms of domestic violence on their status. Women crises center of District Kohat, Khyber Pakhtunkhwa Pakistan was the universe of the study. The research sample was comprised of 30 married women. The data were collected through the interviews schedule and questionnaire with the subjects.

$$
\begin{aligned}
& \text { تلخيصِ مقال }
\end{aligned}
$$

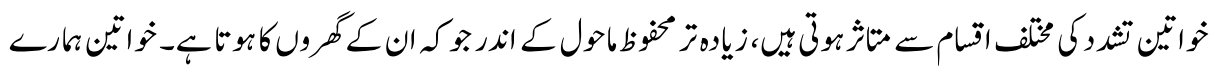

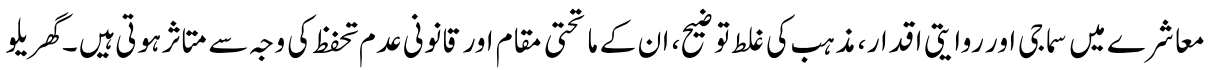

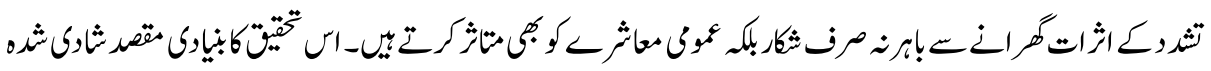

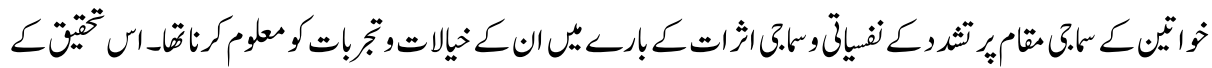

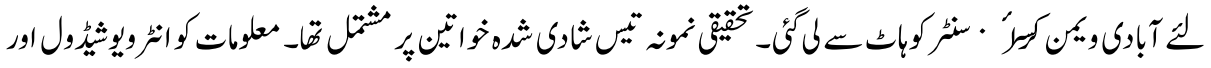

$$
\begin{aligned}
& \text { موالنامس ع اكماكيآيا- }
\end{aligned}
$$

Key Words: Status, Women, Domestic, Violence, Impacts, Psychological, Social. 


\section{Introduction}

Domestic violence is the type of violence that takes place in home. Domestic violence against women controls and restricts women in order to preserve social structure which becomes a mean of shifting male domination in the home and at the societal level (e.g., Khan et al. 1990). For example, Holden (2003) argues that domestic violence implies to violent and assaultive attitudes that one partner is using versus their next associate. This is also recognized as affectionate companion violence, is a device of violent conduct that is used by one person to attain influence and authority over another. According to United States office on domestic violence (2008), domestic violence can be composed of the use of corporeal, psychological and social violence, oral and sentimental exploitation, persecuting and financial abuse. In previous some decades the women movements all over the world has challenged violence against women as the highest frequent utilization of violence as well as subordination by men. Annan (2004) points out that as far as violence persist, the demand regarding accomplishing actual improvement in relation to excellence, progress, and peace cannot be made. According to United Nations Declaration on the Elimination of Violence Against Women (CEDAW) violence as; "Any act of gender-based violence that results in or is likely to result in physical, sexual or psychological harm or suffering to women and includes threats of such acts, coercion or arbitrary deprivation of liberty whether in public or in private life" (Samoa Family Health and Safety Study, 2012).

A study conducted by the National Violence Against Women (NVAW) stated that, almost every year 1.5 million women are raped and corporeally abused by their close partners (Tjaden et al. 1998). The most important kinds of domestic violence are emotional, physical, sexual and psychological. Physical violence refers to slapping, shaking, beating, strangulation, burning, kicking, and threats with a weapon and other forms of physical abuse. Emotional abuse affects mental health and includes excessive possessiveness, jealousy, intimidation, insult, harassment, and constant belittling and humiliation (Dutton et al. 1988 rev. 1995).

According to a press briefing (2010) arranged by Aurat Foundation to released its 1 st BiAnnual Report on "Situation of Violence against Women in Pakistan", From January to June 2010 a total of 4069 events of violence were certified, out of which 940 cases of violence were enrolled from Sindh, 2690 cases of violence were from Punjab, 342 were from the Khyber Pakhtunkhwa (KP), 56 were from Baluchistan and 41 were from Islamabad. According to the Report of Aurat Foundation (2010), during January- June, 2010, 342 incidents of violence against women happened in 23 districts of KP. Out of the total 342 cases of violence against women in KP, there were 54 cases of domestic violence, 30 incidents of suicide, 161 cases of killing, 11 of honor killing, 4 cases of 
rape/gang rape, 37 cases of kidnapping, 1 case of Sexual Assault \& Acid Throwing and, 43 cases of diversified nature.

\section{Literature Review}

It is projected that domestic violence is experienced by one in every four women during her life time (Tjaden et al. 2000). Domestic violence between couple is not restricted to the home settings only; it could also take place in places outside the home. Factors such like low socioeconomic status, frequent unemployment, no social support and lowincome occupations from friends, family and the society generate huge level of strain. Flower (2000) speculated that people who are able to determine their conflicts with violence use violence as a procedure of managing through these kinds of stressors. The Council of Europe has declared that the main causation of demise and disability for all women aged 16 to 44 is domestic violence (TSSA Annual conference in Belfast, 2004). The repercussions of violence against women go far ahead critical physical injury to the target. Psychological sufferings and the risk of additional violence, spoil a woman's ego, destroying her capability to defend herself or to carry on action against her oppressor. In the developing states, it is approximated that 5 percent of the working time is lost by women because of illness or physical impairment results from gender-based violence (TSSA Annual conference in Belfast, 2004).

Domestic violence is not merely limited to corporeal aggression taking place on a mate or companion. There are many other categories of domestic violence. It includes emotional exploitation, aloofness, frightening as well as economic abuse. Physical exploitation of a spouse can include beating, shoving, trembling, forbidding, squeezing, punching or using ammunition to cause physical damage. Wormer and Fred (2010) illustrated, United Nations has been described dowry deaths as a type of domestic violence. Emotional violence and disgrace may contain unjust and continues disapproval, name calling, and making victim's considers with the intention of they contain no value. Normally, an abuser will keep the sufferer cut off from others, moreover will respond aggressively to every external interest that the mistreated spouse might try to chase. The offender might resort to blackmailing along with threatening. It may involve ruining possessions, using ammunitions, creating intimidating expressions or abusing a household. Monetary control is also an instrument of the violent partner. Rodriguez (2012) reports that Acid attacks in Pakistan come to worldwide concentration after releasing the documentary in 2012 by Sharmeen Obaid-Chinoy called Saving Face. By regulating the sufferers approach to capital and resources, an exploiter directs the sufferer's liberty and admittance to facilitate (Hudson, 2011). Types of domestic violence other than physical that is widespread in Pakistan, which result in defacement or death consists of acid burning, stove burning, and honor killing. Enforced marriages which comprise adolescent marriages, prior to the right of marriage with a female (Haq Bakhshwan), watta satta 
(exchange) marriages and swara (giving of women in substitute of a conciliation) are types of domestic violence with the purpose of integrating basics of corporeal, emotional and psychological abuse (Khan N.A, 2001).

A study conducted in 2009 by Human Rights Watch, it is projected that between 70 and 90 percent of women in Pakistan have suffered various forms of violence (Gosselin, 2009). Hansar (2007) argues that a projected 5000 women are killed annually from domestic violence, with thousands of others disabled or maimed. According to Khan N.A, (2005) "conditions of Human civil rights 2004" published by the Human Rights Commission of Pakistan (HRCP) "information compile through the HRCP until the ending of October 2004 indicated that 91 women fell victim to burnings out of which 43 were burnt after accidents involving stoves and 48 were set on fire. The causes of the burns in other cases were not reported. The majority of the victims were vitally burnt. Aimal (2003) reports, Women have reported attacks ranging from corporal to mental and sexual violence from partners, in-laws and relatives. Besides that in a huge amount of cases, accidents caused through stoves might in reality contain intentional burnings. Data collected through the HRCP up to the end of October showed that 464 women fell victim to honor killing, as well as Karo Kari. 384 killings have been carry out on allegations of having illegal affairs, 151 murders were carried out by husbands (Khan N.A, 2001)."

Domestic violence has long-standing unusual and far-ranging effects on victims. These effects can be equally psychological and corporal. There are varied corporeal health effects of domestic violence; however victims are also identified to experience mental and physical troubles as a consequence of domestic violence. Beating is the sole most essential reason of harming towards women; further noteworthy are rapes and vehicle accidents (O'Reilly, 1983). Therapeutic disorder like hypertension or diabetes might be provoked in sufferers of domestic violence as the abuser may perhaps not allow them to access to medication or satisfactory therapeutic care (Persona, 1992). Sufferers might practice corporal damage (laceration, bruise, broken down skeleton, skull injuries, and inner blood loss), chronic pelvic ache, abdominal and gastrointestinal complaints, sexually transmitted diseases, regular vaginal and urinary strip infection, and HIV (Jones \& Horan, 1997). The psychological and emotional exploitation inflict by batterers possibly have longer period impacts and might be further expensive towards take care of in the short-run than corporal damage (Straus, 1986, 1988, 1990). Depression remains the prime reaction, with $60 \%$ of battered women reporting depression (Barnett, 2000). In addition, battered women are at bigger threat used for suicide attempts, with $25 \%$ of suicide attempts by Caucasian women and $50 \%$ of suicide attempts by African American women preceded by violence (Fischbach \& Herbert, 1997). In addition, offspring may possibly build up symptom of depression, nervousness, or PTSD (Harway \& Hansen, 1994). Sufferers frequently lose their job as of non-attendance owing to sickness as an outcome of the violence (Kurz, 1989). 


\section{Method of Research}

The following method was adopted for conducting this research and then on the basis of collected data and findings from the respondents the hypothesis were tested related to psycho-social impacts of domestic violence on women.

\section{Population}

The population was the women crises center, situated in District Kohat of Khyber Pakhtunkhwa, Pakistan.

\section{Sampling Design}

A sample of 30 married women was purposefully selected from the target population as respondents of the study.

\section{Procedure}

The data collection methodology was comprised of structured Interview schedule as well as Questionnaire; because of the reason that 13 respondents were literate and 17 were illiterate. Keeping in mind the cultural sensitivity towards the male female interaction the researcher hired the services of a female data collector for collection of data.

\section{Hypothesis}

Following hypothesis was tested on the basis of data collection and findings from the data.

Research Hypothesis: "Domestic violence negatively affects the women psycho-social state".

Alternate Hypothesis: "Domestic violence has no affects on the women psycho-social state."

\section{Results and Discussion}

Findings pertaining to Domestic Violence: Prevalence and its Psycho-social impacts on women in Pukhtoon Society are given and discussed in this chapter under various sections and sub sections. Table 4.1 carries personal information about respondents which consists of age groups, educational status, level of education and types of marriage.

Out of total 30 respondents, 15 being $50 \%$ belonged to age group of $15-26,12$ being $40 \%$ belonged to age group of $27-35,02$ respondents being $6.7 \%$ belonged to age group of 3646 and 01 respondents being $3.3 \%$ belonged to age group of 47-55. According to 
Rennison M. (2001) findings Women aged 16 to 24 experiences the highest rate of partner violence per capita. This Table also shows the educational status of the respondents. Out of total $30(100 \%)$ respondents, 13 respondents being $43.3 \%$ were literate, while 17 respondents being 56.7\% were illiterate. The Table further shows the educational level of the respondents. Out of 13 literate respondents, 10 respondents being $33.3 \%$ were the primary to middle level of education, 02 respondents being $6.7 \%$ were secondary to higher secondary level of education and 01 respondent being $3.3 \%$ have attained the higher education. The Table-01 further shows types of marriages of the respondents. Out of total $30(100 \%)$ respondents, 02 being $6.7 \%$ were married by choice, 05 respondents being $16.7 \%$ were married by arrange, 01 respondent being $3.3 \%$ was married by sawara, 10 respondents being $33.3 \%$ were married by cousinship and 12 being $40 \%$ were married by exchange.

Table 4.1

Showing Personal Information of the Respondents

\begin{tabular}{|c|c|c|c|c|c|c|c|c|}
\hline \multirow{2}{*}{$\begin{array}{c}\text { Age } \\
\text { Groups }\end{array}$} & Respondents & \multicolumn{2}{|c|}{$\begin{array}{c}\text { Educational } \\
\text { status }\end{array}$} & \multicolumn{2}{c|}{ Level of Education } & \multicolumn{2}{c|}{ Types of Marriage } \\
\cline { 3 - 9 } & & Literate & Illiterate & $\begin{array}{c}\text { Primary- } \\
\text { Middle }\end{array}$ & $\begin{array}{c}\text { High-Higher } \\
\text { secondary }\end{array}$ & $\begin{array}{c}\text { Higher } \\
\text { Education }\end{array}$ & Choice & $02(6.7 \%)$ \\
\hline $15-26$ & $15(50 \%)$ & $7(23.3 \%)$ & $8(26.7 \%)$ & 07 & 0 & 0 & Arrange & $05(16.7 \%)$ \\
\hline $27-35$ & $12(40 \%)$ & $5(16.7 \%)$ & $7(23.3 \%)$ & $02(6.7 \%)$ & $02(6.7 \%)$ & $01(3.3 \%)$ & Swara & $01(3.3 \%)$ \\
\hline $36-45$ & $02(6.7 \%)$ & $1(3.3 \%)$ & $1(3.3 \%)$ & $01(3.3 \%)$ & 0 & 0 & Cousinship & $10(33.3 \%)$ \\
\hline $46-55$ & $01(3.3 \%)$ & 0 & $1(3.3 \%)$ & 0 & 0 & 0 & Exchange & $12(40 \%)$ \\
\hline Total & $\mathbf{3 0 ( 1 0 0 \% )}$ & $\begin{array}{c}\mathbf{1 3} \\
(\mathbf{4 3 . 3 \% )}\end{array}$ & $\begin{array}{c}\mathbf{1 7} \\
\mathbf{( 5 6 . 7 \% )}\end{array}$ & $\begin{array}{c}\mathbf{1 0} \\
\mathbf{( 3 3 . 3 \% )}\end{array}$ & $\begin{array}{c}\mathbf{0 2} \\
\mathbf{( 6 . 7 \% )}\end{array}$ & $\begin{array}{c}\mathbf{0 1} \\
\mathbf{( 3 . 3 \% )}\end{array}$ & Total & $\begin{array}{c}\mathbf{3 0} \\
(\mathbf{1 0 0} \%)\end{array}$ \\
\hline
\end{tabular}

The Table-4.2 shows the Physical violence status of the respondents. All of the $30(100 \%)$ respondents told that they were being beaten. Hansar (2007) finds that a projected 5000 women are killed annually from physical domestic violence. The Table further shows the detail about the tools used for beating of the respondents. All of the $30(100 \%)$ respondents told that they were being beaten with certain tools. WHO (2005) states that women who are experiencing physical violence are also beaten through multiple types of tools. The Table also shows the persons who beat them. The 17 respondents being $56.7 \%$ told that they were being beaten by their husbands, 06 respondents being $20 \%$ told that they were being beaten by their husband mothers, 05 respondents being $16.7 \%$ acknowledged that they were beaten by their husband's father and 02 respondents being $6.7 \%$ told that they were being beaten by their in- laws. A study conducted by UNIFEM (2005) finds that majority of the husband beats their wives in homes. This Table further gives information about the types of Tools used for beating of the respondents. Out of total $30(100 \%)$ respondents, 10 respondents being $33.3 \%$ told that they were being beaten with the stick, 15 respondents being $50 \%$ told that they were beaten through slapping and 05 respondents being $16.7 \%$ told that they were being beaten through 
kicking. According to Macro International (2005) women are beaten by their partner through slapping, kicking, dragging and threatened her with use of Gun, knife or other weapon against her. Matud M. Pilar (2005) conducted a research on the psychological impacts on domestic violence. In his research he conducted interview from abused women consisted of 240 participants between 17 and 68 years old, he find out that majority of the male physically abuse their women such as pushing, slapping, hitting with a fist or object and choking.

Table 4.2

Showing Status of Physical Violence of the Respondents

\begin{tabular}{|l|l|c|c|c|c|c|c|c|c|}
\hline $\begin{array}{l}\text { You are } \\
\text { Being } \\
\text { Beaten }\end{array}$ & Respondents & $\begin{array}{l}\text { Tools Use for } \\
\text { Beating }\end{array}$ & \multicolumn{4}{|c|}{ Persons Beats you } & \multicolumn{2}{|c|}{$\begin{array}{l}\text { Types of tools use for } \\
\text { beating }\end{array}$} \\
\cline { 3 - 9 } & Yes & No & Husband & $\begin{array}{c}\text { Husband } \\
\text { mother }\end{array}$ & $\begin{array}{c}\text { Husband } \\
\text { father }\end{array}$ & $\begin{array}{c}\text { In } \\
\text { laws }\end{array}$ & $\begin{array}{c}\text { Use of } \\
\text { stick }\end{array}$ & $10(33.3 \%)$ \\
\hline Yes & $30(100 \%)$ & $\begin{array}{c}30 \\
(100 \%)\end{array}$ & 0 & $\begin{array}{c}17 \\
(56.7 \%)\end{array}$ & $6(20 \%)$ & $5(16.7 \%)$ & $\begin{array}{c}2 \\
(6.7 \%)\end{array}$ & Slapping & $15(50 \%)$ \\
\hline No & 0 & 0 & 0 & 0 & 0 & 0 & 0 & Kicking & $05(16.7 \%)$ \\
\hline Total & $\mathbf{3 0}(\mathbf{1 0 0 \% )}$ & $\begin{array}{c}\mathbf{3 0} \\
\mathbf{( 1 0 0 \% )}\end{array}$ & & $\begin{array}{c}\mathbf{1 7} \\
\mathbf{( 5 6 . 7 \% )}\end{array}$ & $\mathbf{6 ( 2 0 \% )}$ & $\mathbf{5 ( 1 6 . 7 \% )}$ & $\begin{array}{c}\mathbf{2} \\
(\mathbf{6 . 7} \%)\end{array}$ & Total & $\mathbf{3 0}(\mathbf{1 0 0 \% )}$ \\
\hline
\end{tabular}

The Table 4.3 shows Status of Prevalence of Violence of the respondents. Out of the total $30(100 \%)$ respondents, 20 being $66.7 \%$ agreed that lack of money is a causative responsible factor for their violence, while remaining 10 respondents being $33.3 \%$ disagreed. Michael L. Benson \& Greer Litton Fox (2002) reports that domestic violence is more than three times as likely to happen as couple are experiencing high levels of economic twist as when they are experiencing little levels of economic strain. Table further shows that out of total $30(100 \%)$ respondents, 12 respondents being $40 \%$ were agreed that their husbands were aware about women rights in Islam, while remaining 18 respondents being $60 \%$ told that their husbands were unaware. The table also shows that out of $30(100 \%)$ respondents, 03 respondents being 10\% told that they experienced violence daily, 15 respondents being $50 \%$ told that they experienced violence frequently, 07 respondents being $23.3 \%$ were of the view that they experienced violence weekly and 05 respondents being $16.7 \%$ were of the view that they experienced violence monthly. UN Department of Public Information published a report (2009) stated that up to 70 per cent of women experience violence in their lifetime. The table further indicates that out of total $30(100 \%)$ respondents, 05 respondents being $16.7 \%$ told that they have been living with their husband's families, 12 respondents being $40 \%$ told that they have been living with their mother's families, 08 respondents being $26.66 \%$ told that they have been living in Darr ul Kafala (Shelter) and 05 respondents being $16.66 \%$ told that they have been living at different places. 
Table 4.3

Showing Status of Prevalence of Violence of the Respondents

\begin{tabular}{|c|c|c|c|c|c|c|c|}
\hline \multirow{3}{*}{$\begin{array}{l}\text { Lack of } \\
\text { money } \\
\text { Cause } \\
\text { Violence } \\
\text { Yes }\end{array}$} & \multirow{3}{*}{$\begin{array}{c}\text { Respondents } \\
20(66.7 \%)\end{array}$} & \multicolumn{2}{|c|}{$\begin{array}{l}\text { Husband knows } \\
\text { about women } \\
\text { Rights in Islam }\end{array}$} & \multicolumn{2}{|c|}{$\begin{array}{c}\text { Frequency Of } \\
\text { Experiencing Violence }\end{array}$} & \multicolumn{2}{|c|}{ Living Arrangements } \\
\hline & & Yes & $12(40 \%)$ & Daily & $03(10 \%)$ & $\begin{array}{c}\text { Living with } \\
\text { husband family }\end{array}$ & $\begin{array}{c}05 \\
(16.7 \%)\end{array}$ \\
\hline & & & & Frequently & $15(50 \%)$ & $\begin{array}{l}\text { Living with } \\
\text { mother family }\end{array}$ & $12(40 \%)$ \\
\hline \multirow[t]{2}{*}{ No } & \multirow[t]{2}{*}{$10(33.3 \%)$} & \multirow[t]{2}{*}{ No } & \multirow[t]{2}{*}{$18(60 \%)$} & Weekly & $\begin{array}{c}07 \\
(23.3 \%) \\
\end{array}$ & $\begin{array}{c}\text { Dar ul Kafala } \\
\text { (Shelters) }\end{array}$ & $\begin{array}{c}08 \\
(26.7 \%) \\
\end{array}$ \\
\hline & & & & Monthly & $\begin{array}{c}05 \\
(16.7 \%)\end{array}$ & Any other & $\begin{array}{c}05 \\
(16.7 \%)\end{array}$ \\
\hline Total & $100(33.3 \%)$ & Total & $\begin{array}{c}30 \\
(100 \%)\end{array}$ & Total & $\begin{array}{c}30 \\
(100 \%)\end{array}$ & Total & $\begin{array}{c}30 \\
(100 \%)\end{array}$ \\
\hline
\end{tabular}

The Table 4.4 shows that all out of 30 respondents being $100 \%$ agreed that they were insulted and criticized just for nothing. The Table also shows that all the 30 respondents being $100 \%$ agreed that the women lost their social status due to violence. The Table also shows the Respondents who felt Isolation, when they became a victim of domestic violence. All 30 Respondents being 100\% acknowledged that they felt isolation due to domestic violence. Echeburua and Corral (1998) pointed out that majority of the women feel social isolation due to domestic violence. The Table also shows that out of $30(100 \%)$ respondents, 03 respondents being 10\% acknowledged that every time they were taken to the doctor when they were ill, 10 respondents being 33.3\% acknowledged that sometimes they were taken to the doctor during illness and 17 respondents being $56.7 \%$ were of the view that they were never taken to doctor during their illness. The Table also indicates the attitude of the people toward the victims of domestic violence. Out of total $30(100 \%)$ respondents, 10 being $33.3 \%$ recognized co-operative attitude of the people towards them, 17 respondents being $56.7 \%$ recognized normal attitude of the people towards them and 03 respondents being $10 \%$ recognized strict attitude of the people towards them. Salazar (2005) finds out that community attitude should be normal towards victims of domestic violence.

Table 4.4: Showing Social Aspects of Domestic Violence

\begin{tabular}{|c|c|c|c|c|c|c|c|c|c|}
\hline \multirow{2}{*}{$\begin{array}{l}\text { Insult or } \\
\text { criticize } \\
\text { just for } \\
\text { nothing }\end{array}$} & \multirow[t]{2}{*}{ Respondents } & \multicolumn{2}{|c|}{$\begin{array}{c}\text { Impacts of } \\
\text { Violence on social } \\
\text { status }\end{array}$} & \multirow{2}{*}{\multicolumn{2}{|c|}{$\begin{array}{c}\text { Feeling of isolation } \\
\text { due to violence }\end{array}$}} & \multicolumn{2}{|c|}{$\begin{array}{l}\text { Taken to Doctor } \\
\text { when Ill }\end{array}$} & \multicolumn{2}{|c|}{$\begin{array}{c}\text { Attitude of People } \\
\text { towards victims of } \\
\text { violence }\end{array}$} \\
\hline & & & & & & Every time & 03 & Cooperative & $10(33.3 \%)$ \\
\hline Yes & $30(100 \%)$ & Negative & $30(100 \%)$ & Yes & $30(100 \%)$ & Sometime & $\begin{array}{c}10 \\
(33.3 \%) \\
\end{array}$ & Normal & $17(56.7 \%)$ \\
\hline No & 0 & Positive & 0 & No & 0 & Never & $\begin{array}{c}12 \\
(56.7 \%)\end{array}$ & Strict & $03(10 \%)$ \\
\hline Total & $30(100 \%)$ & Total & $30(100 \%)$ & Total & $30(100 \%)$ & Total & $\begin{array}{c}30 \\
(100 \%)\end{array}$ & Total & $30(100 \%)$ \\
\hline
\end{tabular}


The Table 4.5 shows psychological aspect of domestic violence. The table shows that all the 30 respondents being 100\% experience the Psychological Problems due to violence. The present study also confirm walker's (1999) reflection that "The issue encountered by psychologist studying domestic violence, majority of the victims of domestic violence are experiencing psychological problems". Table also indicates that $30(100 \%)$ respondents, 20 respondents being $66.7 \%$ agreed that they experienced thinking of committing suicide when they became victim of domestic violence, while remaining 10 respondents being $33.3 \%$ disagreed. Through telephone surveys, seedat et al (2005) found that abused women were more likely to attempt suicide. The table further shows the nature of Psychological Problems which were felt by the respondents due to incidence of violence. 12 respondents being $40 \%$ agreed that they experienced tension, 09 respondents being 30\% agreed that they experienced depression, 03 respondents being $10 \%$ agreed that they experienced anxiety, 01 respondent being 3.33\% agreed that she had negative thoughts, 01 respondent being 3.3\% agreed that she experienced fear and 04 respondents being $13.3 \%$ experienced that they experienced inferiority. Echeburua and Corral (1998) stated that women develop feelings of guilt, social isolation and emotional dependence on her abusive partner.

Table 4.5

Showing Psychological Aspects of Domestic Violence

\begin{tabular}{|c|c|c|c|c|c|}
\hline $\begin{array}{l}\text { Victim feel } \\
\text { psychological } \\
\text { problems }\end{array}$ & Respondents & \multicolumn{2}{|c|}{$\begin{array}{l}\text { Think about } \\
\text { suicide } \\
\text { Attempt due to } \\
\text { violence }\end{array}$} & \multicolumn{2}{|c|}{$\begin{array}{c}\text { Nature of psychological } \\
\text { problems experienced }\end{array}$} \\
\hline \multirow[t]{3}{*}{ Yes } & \multirow[t]{3}{*}{$30(100 \%)$} & \multirow[t]{3}{*}{ Yes } & \multirow{3}{*}{$\begin{array}{c}20 \\
(66.7 \%)\end{array}$} & Tension & $12(40 \%)$ \\
\hline & & & & Depression & $09(30 \%)$ \\
\hline & & & & Anxiety & $03(10)$ \\
\hline \multirow[t]{3}{*}{ No } & \multirow[t]{3}{*}{0} & \multirow[t]{3}{*}{ No } & \multirow[t]{3}{*}{$\begin{array}{c}10 \\
(33.3 \%)\end{array}$} & $\begin{array}{l}\text { Negative } \\
\text { thoughts }\end{array}$ & $01(3.3 \%)$ \\
\hline & & & & Fear & $01(3.3 \%)$ \\
\hline & & & & Inferiority & $04(13.3 \%)$ \\
\hline Total & $30(100 \%)$ & Total & $\begin{array}{c}30 \\
(100 \%)\end{array}$ & Total & $30(100 \%)$ \\
\hline
\end{tabular}

\section{Conclusions}

Domestic violence remains one of the least legally addressed issues in Pakistan. The number of domestic violence cases is alarming and there is no actual information or data available which can measure the size. It is clear from this research study that domestic violence is one of the serious problems of the society today. It damages all the social relations among the society. The domestic violence causes Psychological and social 
impacts to married women, they feel tension, depression, anxiety etc. It is recommended that poverty should be alleviated and education for all should be promoted. There should be an integrated national strategy coordinated with different departments of the judiciary, social welfare departments, and law enforcement agencies and with the participation of the public to devise such plans which ensure the proper treatment of victims and provide them sufficient support to settle their disputes and improve life. There should be made New Legislation to criminalize domestic violence.

\section{References}

Ajmal, Umer Bin (2012). "Domestic violence". Dawn. Retrieved 28 July 2012.

Critical Issues for Women in Pakistan Retrieved on February 5, 2013, www.adb.org/ Documents/Books/Country.../Women...Pakistan/chap02.pdf

C. J. Newton (2001). Domestic Violence: An Overview", MA, Learning Specialist and published in the Find Counseling.com (formerly TherapistFinder.net) Mental Health Journal, Retrieved on February 02, 2013, http://www.findcounseling.com/ journal/domestic-violence/

Domestic Violence in General (2013). Retrieved on January 09, 2013, http://social.jrank. org/pages/212/Domestic-Violence.html

TSSA Policy (2004). "Domestic Violence Policy”. TSSA Annual Conference in Belfast. Retrieved on January 25, 2013 from http://www.tssa.org.uk/article48.php3?id_article $=2046$

Dutton DG (1988 rev.1995). The Domestic Assault of Women: Psychological and Criminal Justice Perspectives. Boston: Allyn and Bacon, Inc. Retrieved on January 07, 2013.

Gosselin, Denise Kindschi (2009). Heavy Hands: An Introduction to the Crime of Intimate and Family Violence (4th ed.) Prentice Hall. p, 13.

Goldsmith, T. (2006). What Causes Domestic Violence? Psych Central. Retrieved on April 10, 2013, from http://psychcentral.com/lib/2006/what-causes-domesticviolence/

Hansar, Robert D. (2007). "Cross-Cultural Examination of Domestic Violence in China and Pakistan". In Nicky Ali Jackson. Encyclopedia of Domestic Violence (1st ed.). Routledge. p, 211. 
Hussaini, M. Mohammad (2011). An Nikah (The Marriage) Retrieved on February 01, 2013, http://www.soundvision.com/info/Islam/marriage.nikah.asp

Hudson A (2012). Types of Domestic Violence, Retrieved December 15, 2012, http://www.ehow.com/facts_5024685 types-domestic-violence.html

Khan N.A (2004). Country Report-Pakistan, Retrieved on December 12, 2012 , www.unafei.or.jp/.../No69 16PA Khan.pdf

Khan NS, Zia AS (1990). Unveiling the Issues Pakistani Women's Perspective on Social, Political and Ideological Issues, Defining, Understanding and Challenging Violence against Women. Lahore: ASR, Retrieved on February 03, 2013.

Long Term Effects of Domestic Violence (2013). Retrieved on February 05, 2013, http://www.aardvarc.org/dv/effects.shtml

Macro International (2005). Demographic and Health Surveys, Questionnaires and Modules - Questionnaire Forms, Domestic Violence Module. www.measuredhs. com/pubs/pdf/DHSQM/DHS5_Module_Domestic_Violence. pdf

Press Briefing (2010). Incidents of Violence against Women in Pakistan, Reported during January to June 2010. Retrieved on February 10, 2013, www.raahnuma.org/wpcontent/uploads/2011/07/PDF-Aurat-Foundation-VAW-press-release-Jan-to-Jun2010.pdf

Rennison M. (2001). Intimate Partner Violence and Age of Victim, 1993-1999. Bureau of Justice Statistics: Special Report. Washington, DC: U.S. Department of Justice. Publication NCJ 187635.

Rodriguez, Alex (2012, May 29). Pakistan Offers Little Justice for Victims of Acid Attacks. Los Angeles Times.

Meyer C, Negative Effects of Domestic Violence, Retrieved on December 07, 2012, http://divorcesupport.about.com/od/abusiverelationships/p/effects_abuse.htm

Office on Violence Against Women (2008). About Domestic Violence, Retrieved on January 22, 2013, http://www.ovw.usdoj.gov/domviolence.htm

Samoa Family Health and Safety Study (2012). Retrieved on December 20, 2012, http://www.spc.int/hdp/index2.php?option=com_docman\&task=doc_view\&gid $=6$ $\underline{8 \& \text { Itemid }=44}$ 
World Health Organization (2005). WHO multi-country study on women's health and domestic violence against women: Summary Report of Initial Results on Prevalence, Health Outcomes and Women's Responses. Geneva, Switzerland: WHO. Retrieved on February 10, 2013

Dr. Mamoon Khan Khattak is Assistant Professor and Inchage Chairperson in the Department of Social Work, Kohat University of Science \& Technology (KUST), Kohat.

Aamir Khan Bangash is M.Sc Student in the Department of Social Work, Kohat University of Science \& Technology (KUST), Kohat.

Dr. Sabir Michael is Assistant Professor in the Department of Social Work, University of Karachi.

Zubaida Khatoon Khattak is Doctoral Scholar in the Department of Economics University of Peshawar. 